\title{
Knowledge and attitude of medical students on brain death and organ donation
}

\author{
Elamurugan Tirthar Palanivelu, Sudarshanan Sundaramurthi, Shanmugam Dasarathan, Sreenath Gubbi Shamana, \\ Vikram Kate*
}

From International Summit on Emergency Medicine and Trauma 2014

Puducherry, India. 12-16 February 2014

\section{Objective}

To assess the knowledge, attitudes of medical students regarding brain death and organ donation from brain dead.

\section{Methods}

The study was conducted among the final year medical students of JIPMER, Puducherry using a 22-item questionnaire during the academic year 2013.

\section{Results}

A total of 90 questionnaires were assessed. Based on the students' response the following opinions were noted. $25 \%$ of students believed brain death is equal to human death. $91 \%$ students responded that there is no treatment for brain dead patients. $62 \%$ of students accepted the concept of brain death. Religious and social reasons were the commonest reason for non-acceptance of brain death among the students. $97 \%$ of students believe that organ donation can save a life. $93 \%$ of students think that there is difference between organ transplantation from brain dead and cadaver. In students' opinion, mutilation of the body was found to be the main reason for not accepting organ removal from brain dead patients.

\section{Conclusion}

Religious and social factors were the major hindering factors for acceptance of brain death and organ donation. Knowledge of brain death and organ donation was lacking among medical students.

* Correspondence: drvikramkate@gmail.com

Department of Surgery, Jawaharlal Institute of Postgraduate Medical Education and Research, Puducherry, India
doi:10.1186/1865-1380-7-S1-05

Cite this article as: Palanivelu et al:: Knowledge and attitude of medical students on brain death and organ donation. International Journal of Emergency Medicine 2014 7(Suppl 1):05. (c) 2014 Palanivelu et al; licensee Springer This is an Open Access article distributed under the terms of the Creative Commons Attribution License (http://creativecommons.org/licenses/by/2.0), which permits unrestricted use, distribution, and reproduction in any medium, provided the original work is properly credited.
Submit your manuscript to a SpringerOpen ${ }^{\circ}$ journal and benefit from:

- Convenient online submission

- Rigorous peer review

- Immediate publication on acceptance

- Open access: articles freely available online

- High visibility within the field

- Retaining the copyright to your article

Submit your next manuscript at $>$ springeropen.com 